\title{
The Structure of Workaholism and Types of Workaholic
}

\begin{abstract}
The aim of the study presented was to verify empirically a conception of workaholism as a multidimensional syndrome. The study also investigated the notion of 'functional' and 'dysfunctional' types of workaholic, on the basis of the participants' cognitive evaluations of their quality of life. The research group comprised Polish managers who had graduated with, or were studying to attain, a Master's degree in Business Administration. The 137 participants completed a set of questionnaires that were based on five different research tools. Confirmatory factor analysis supported the theory that workaholism has a three-dimensional structure that includes behavioural, cognitive, and affective dimensions. Using cluster analysis, three types of worker were identified, two of which represented types of workaholic with different scores for the dimensions of workaholism and for aspects of quality of life. The research demonstrated that workaholism is a three-dimensional construct. It enabled the integration of different perspectives and also confirmed that dysfunctional and functional types of workaholic exist. Furthermore, this paper provides practical insights about workaholism for practitioners of human resources that can be used in the selection and evaluation of employees.
\end{abstract}

Key words: workaholism, types of workaholic, quality of life, well-being

\section{Introduction}

An intensive work, which takes 60 or 70 hours per week, is a significant characteristic of contemporary professional activities. The study, a part of which is presented here, includes all its spectrum. When we take a paradigm into account, it means the acceptance of pathogenesis and salutogenesis approaches to study causes, symptoms and functions of extreme behaviours. Regarding the methodology, these two approaches enable to study various manifestations of working hard: work addiction as well as work engagement, which is related to the stable level of satisfaction (Malinowska, 2014). The main goal of the study was the verification of the workaholism structure and the elaboration of typology of workaholics which include behavioural, cognitive and emotional components. We also explain motivational aspects of workaholism, which is out of the scope of this article and is presented in other work (i.e., Malinowska \& Tokarz, 2013).
There is not one dominant conceptualization which explains causes and mechanisms of workaholism, therefore we refer to the Integrated Model of Work Motivation (Latham, 2007, see Malinowska, 2014). This model refers to the theory of motivation proposed by McClelland (1986) in a group of cognitive "expectancy and value theories" (see Madsen, 1974/1980).

Studies on intensive work are especially important because it might have a wide range of consequences for the functioning of individuals, their families (Robinson, Flowers, \& Ng, 2006), and co-workers, as well as the organizations that employ them (Malinowska, Trzebińska, Tokarz, \& Kirkcaldy, 2013). The most fundamental issues are undoubtedly to increase understanding of the structure of workaholism and to identify the forms that it may adopt (Burke, 2000a, 2000b). Consequently, the main aims of the study presented in this paper were twofold: first, to verify the structure of workaholism, on the basis of the proposition of $\mathrm{Ng}$, Sorensen, and Feldman (2007) and, second, to

\footnotetext{
* Institute of Psychology, Jagiellonian University, Cracow, Poland

** Jagiellonian University, Institute of Psychology, Al. Mickiewicza 3, P.O. Box 31-120 Cracow, Poland, d.malinowska@uj.edu.pl
} 
identify different types of workaholic on the basis of the participants' subjective assessments of their quality of life.

\section{Definitions and Structure of Workaholism}

The term 'workaholism' may lead to bias because the name suggests a relationship with alcoholism, a term that has definite negative connotations and is associated with pathology. It should be emphasized that the definition of workaholism as proposed by Oates (1971) has undergone significant changes, and a review of the literature shows that there are now three ways of considering this phenomenon.

The first perspectives is a continuation of the approach adopted by Oates. These conceptualizations concentrate mainly on symptoms of compulsion and obsession; however, they do not include all the characteristics of addiction that are described in the literature (see Griffiths, 2005a, 2005b, 2005c). According to Robinson (1989, 1998), workaholism involves the following qualities: self-imposed demands, compulsive overworking, inability to regulate work habits, an overindulgence in work to the exclusion of major life activities, and neglect of relations with family and friends. The view that workaholism is an addiction that has exclusively negative consequences for the person affected and their environment is also argued by Killinger (1991), Porter (1996), and Paluchowski and Hornowska (2003, 2007).

The second perspective emphasizes the view that workaholism is a positive behaviour, unlike other addictions, which have harmful effects. This definition of workaholism is applied by Cantarow (1979), who understands it to be 'devotion to work'. Machlowitz (1980) takes a similar view, she sees workaholism as a manifestation of the inner need to work hard and for long hours, an activity from which a workaholic derives real pleasure. Friedman and Lobel (2003) also support the idea that workaholism can be an advantage for organization, if working excessively is adjusted to the person's value system.

In the third perspective, workaholism is seen as either a 'positive' or 'negative' behaviour, depending on the type of workaholic. This view is represented by, among others, Scott, Moore, and Miceli (1997), who differentiate between a compulsive-addicted workaholic, a perfectionist workaholic, and an achievement-oriented workaholic. The definitions of a compulsive-addicted workaholic and a perfectionist workaholic include a number of characteristics that are also attributed to addictions and obsessive-compulsive disorders (Griffiths, 2005a, 2005b, 2005c), particularly with respect to attempting to 'cut down' or stop the addictive behaviour completely. In contrast, while achievement-oriented workaholics also value work over other activities and give up activities that are related to personal or family life, they differ from compulsiveaddicted and perfectionist workaholics in that they appear to be able to retain some control over their behaviour. The approach to workaholism that is adopted by Spence and Robbins (1992) should also be considered to be derived from this perspective. According to Spence and Robbins, workaholism is composed of three indicators - feeling driven (internally) to work, involvement in work, and enjoyment of work - that produce two types of workaholic. The level of satisfaction derived from work is the criterion that differentiates workaholics from enthusiastic workaholics.

The perspectives presented above indicates that workaholism is a complex and ambiguous phenomenon. The definitions have different scopes, focus only on cognitive or behavioural aspects, what is more, emphasize clearly pathological or normal features of this syndrome. We can assume that researchers implicite take a pathogenic or salutogenic approach when analysing the workaholism (see Antonovsky, 1979), therefore strengthen causes and consequences of maladaptation and illness or causes of excessive engagement and its positive consequences for a person. The current state-of-the-art makes choosing one definition difficult. It seems essential and necessary to search for a broad and synthetic definitions, which allow to enclose the whole complexity of workaholism, without imposing just one perspective.

In this regard, it is useful to draw attention to a more recent definition, developed by $\mathrm{Ng}$ et al. (2007), which states that "workaholics are those who enjoy the act of working, who are obsessed with working, and who devote long hours and personal time to work" (p. 114). Following the work of Smith and Seymour (2004), Ng et al. argue that three types of mental process or dimension, namely behaviour, cognition, and affect, should be analysed for every type of addiction, including workaholism. Using this tripartite approach, $\mathrm{Ng}$ et al. operationalize the dimensions of workaholism:

- Behavioural dimension: devoting time predominantly to work and limiting time for other activities;

- Cognitive dimension: obsession with work that manifests as a serious involvement in work that cannot be limited or controlled; constant thoughts about work that arise even when the person is not working;

- Affective dimension: positive emotions related to work, which is the main source of satisfaction and pleasure, and negative emotions that appear when the person is not working (e.g., fear, sense of guilt, depression).

The conceptual model of relationships between different workaholism indicators proposed by $\mathrm{Ng}$ et al. (2007) has valuable qualities. First, it is complex: it includes many different indicators of workaholism that are highlighted in the three aforementioned perspectives on workaholism. Second, it is theory-driven: the dimensions of workaholism are operationalized and are based on the research on addictions. The article presents the research results on the verification of the workaholism' structure; however, the study includes analysis of motivational determinants of each of these dimensions (Malinowska, 2014).

It should be noted that, in many of the definitions mentioned, workaholism is regarded as a syndrome that consists of many aspects (e.g., Harpaz \& Snir, 2003). However, these approaches concentrate on only the selected dimensions of workaholism mentioned above, which 
mainly are exclusively cognitive (e.g., Robinson, 1989) or behavioural (e.g., Snir \& Zohar, 2008), and are rarely both cognitive and affective (Spence \& Robbins, 1992) or behavioural and cognitive (Schaufeli, Taris, \& Bakker, 2006).

To verify the structure of workaholism that was proposed by Ng et al. (2007) and, as far as we know, has not been validated so far, we developed a model with nine indicators of workaholism. The indicators were derived from three different tools which measure workaholism and correspond with the proposition of $\mathrm{Ng}$ et al. These three tools were chosen to capture diverse indicators of workaholism because the available single measures enable assessment of only one or two of the three dimensions of workaholism. The workaholism indicators were classified into three overarching dimensions, which are presented schematically in Figure 1. The classification was based on descriptions of indicators delivered by authors of these tools (i.e., Malinowska, Jochymek, \& Tokarz, 2010; Paluchowski \& Hornowska, 2007; Spence \& Robbins, 1992) as well as the content of items which compose each indicator.

To verify the assumed multidimensional structure of workaholism in the sample of Polish employees the following hypothesis was formulated:

\section{Hypothesis 1:}

Workaholism has a three-dimensional structure that includes behavioural, cognitive, and affective dimensions.

\section{Is Workaholism Functional or Dysfunctional?}

The literature on workaholics and the various consequences of workaholism provides various data that show that it cannot be maintained categorically, that the phenomenon has a negative impact on the mental, physical, and social functioning of a person (e.g., Malinowska et al., 2012; McMillan, O’Driscoll, \& Brady, 2004; Vodanovich, Piotrowski, \& Wallace, 2007). For instance, Bonebright, Clay, and Ankenman (2000) demonstrated clear differences between the two types of workaholic, enthusiastic workaholic and workaholic, that were described earlier by Spence and Robbins (1992). Enthusiastic workaholics had a higher level of life satisfaction and sense of purpose in life than workaholics. Buelens and Poelmans (2004) examined these two types of workaholic on the basis of organizational correlates and also found significant differences between them. Employees who belonged to the category of enthusiastic workaholics were more satisfied with their social relationships at work and expressed less intention to leave the company than workaholics.

Indeed, a better understanding of whether the phenomenon should be viewed as functional or dysfunctional could be achieved if researchers were able to differentiate between different types of workaholic. Table 1 summarizes main typologies of workaholic presented in the literature, we indicate the criteria for their differentiation elsewhere (i.e., Malinowska \& Tokarz, 2014). The majority of the typologies differentiate a priori between the form that carries advantages to the individual and the form that has inherent disadvantages. It should be emphasized that the typology developed by Spence and Robbins (1992) as well as van Beek, Taris and Schaufeli (2011) is, to the best of our knowledge, the only one that has been verified empirically. However, similarly to the other approaches presented, it does not include all the aforementioned dimensions of workaholism.

Figure 1. The Hypothesized Model for the Three-Dimensional Structure of Workaholism.

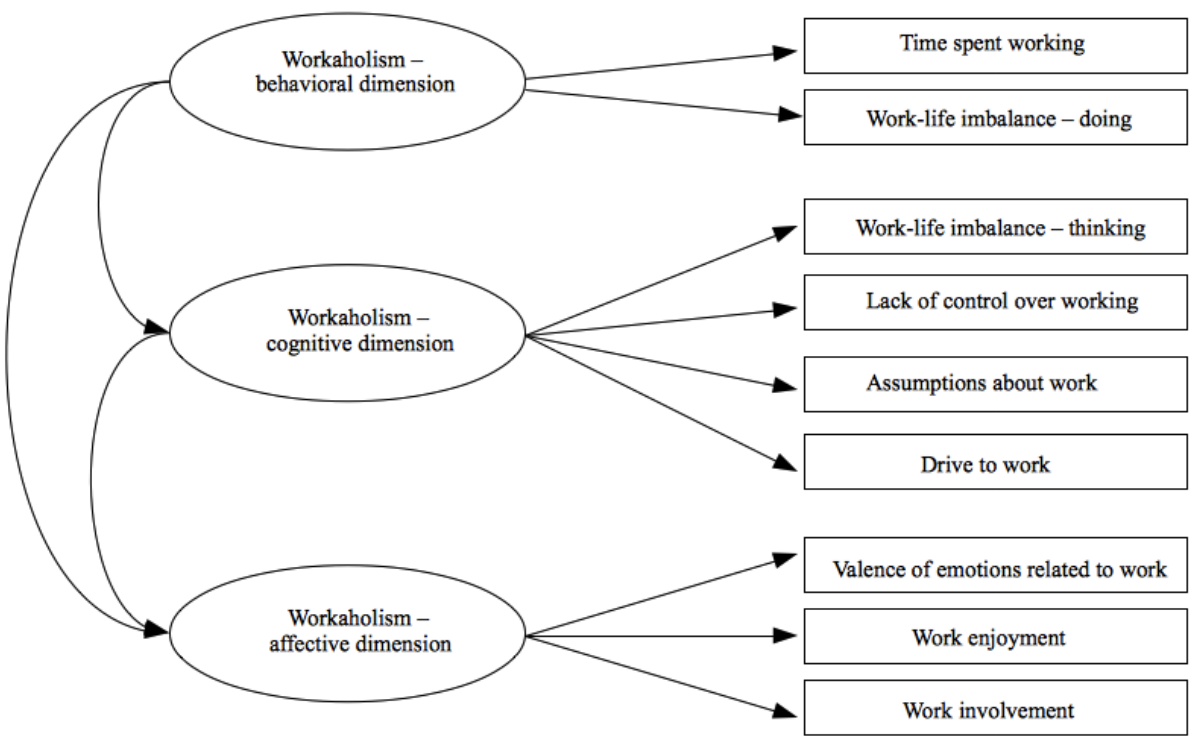


Table 1. Typologies of Workaholics (in chronological order)

\begin{tabular}{|c|c|c|c|}
\hline Author of typology & Type of workaholic & Consequences to an individual & $\begin{array}{c}\text { Empirical } \\
\text { verification }\end{array}$ \\
\hline Oates (1971) & $\begin{array}{l}\text { (1) dyed-in-the-wool workaholic } \\
\text { (2) converted workaholic } \\
\text { (3) situational workaholic } \\
\text { (4) pseudo-workaholic }\end{array}$ & Only negative for all types & No \\
\hline Rohrlich (1981) & $\begin{array}{l}\text { (1) escapist workaholic } \\
\text { (2) obsessive work addicted } \\
\text { (3) competitive work addicted } \\
\text { (4) defensive work addicted }\end{array}$ & Only negative for all types & No \\
\hline Naughton (1987) & $\begin{array}{l}\text { (1) job-involved workaholic } \\
\text { (2) compulsive workaholic }\end{array}$ & Positive for (1), negative for (2) & No \\
\hline Spence and Robbins (1992) & $\begin{array}{l}\text { (1) workaholic } \\
\text { (2) enthusiastic workaholic }\end{array}$ & Negative for (1), positive for (2) & Yes \\
\hline Scott, Moore, and Miceli (1997) & $\begin{array}{l}\text { (1) compulsive-dependent workaholic } \\
\text { (2) perfectionist workaholic } \\
\text { (3) achievement-oriented workaholic }\end{array}$ & Negative for (1), may be positive for (2) and (3) & No \\
\hline Robinson (2000) & $\begin{array}{l}\text { (1) relentless workaholic } \\
\text { (2) bulimic workaholic } \\
\text { (3) attention deficit workaholic } \\
\text { (4) savouring workaholic }\end{array}$ & Only negative for all types & No \\
\hline van Beek, Taris and Schaufeli (2011) & $\begin{array}{l}\text { (1) workaholic } \\
\text { (2) engaged workaholic }\end{array}$ & Negative for (1), positive for (2) & Yes \\
\hline
\end{tabular}

Note. Source: Own elaboration

The ability to identify whether a particular type of workaholic is either functional or dysfunctional is a fundamental step in developing a complete concept of workaholism. Although the standard mode of thinking about health and illness is the model of pathogenesis, in which the factors that are responsible for an illness are sought, a new direction of thinking can be seen in the work of Antonovsky (1979, 1995; Heszen \& Sęk, 2007). Antonovsky (1995) emphasizes the importance of taking both salutogenetic and pathogenetic perspectives into consideration when analysing phenomena related to disorders. ${ }^{1}$ Moreover, the quest for the differentiation of functional and dysfunctional types of workaholic justified by the research on harmonious and obsessive passion in professional work (Burke \& Fiksenbaum, 2008), as well as in sport (e.g., Lafrenière, Jowett, Vallerand, Donahue, \& Lorimer, 2008; Philippe, Vallerand, Andrianarisoa, \& Brunel, 2009). This motivational construct, which indicates a high level versus a low level of integrity (harmonious passion versus obsessive passion) in the relationship between an action and the self, helps to clarify the psychological consequences (positive versus negative) that are related to an activity to which one devotes a lot of time.
Among the early attempts that have been made to differentiate between the types of workaholic, the most promising approach seems to involve health-focused models. These models have been proposed mainly in studies of wellbeing and quality of life in the comparatively new field of positive psychology (e.g., Nakamura \& Csíkszentmihályi, 2003; Seligman \& Csíkszentmihályi, 2000). These authors indicate that subjective assessment of the satisfaction that is derived from life in general, and from various life domains, is essential to understanding quality of life (Diener, 1984, 2006; Levine, 1995). It should be noted that subjective perception of quality of life can be regarded as a hallmark of psychological well-being and optimal functioning. Research (e.g., Veenhoven, 1988, 1991) shows that the higher the quality of life, the higher is the level of professional and social activity, and the more adventurous and long-term the goals, the better is the physical health shown by an individual. However, we do not assert that psychological well-being is equivalent to the concept of health, and we agree with the notion of Wilson and Cleary (1995) that health is constituted jointly by physical, psychological and social well-being. Hence, we assume only that quality of life can be seen as an indicator of optimal functioning.

${ }^{1}$ This approach is implemented, for instance, in the analysis of 'normal' versus 'pathological' forms of perfectionism (Flett \& Hewitt, 2006; Szczucka, 2010). 
If the criteria for the distinction of different types of workaholic are based on a subjective assessment of quality of life, the following hypothesis may be proposed:

\section{Hypothesis 2:}

There are functional and dysfunctional types of workaholic based on three workaholism dimensions who differ with regard to their quality of life, which is measured on the basis of their general satisfaction with life and satisfaction with life domains.

\section{Method}

\section{Participants}

The group of participants consisted of 137 Polish managers who were students or graduates of a Master of Business Administration (MBA) programme. Women comprised $27.7 \%(N=38)$ of the participants, $70.8 \%(N$ $=97)$ were men, and $1.5 \%(N=2)$ did not provide data on sex. The sample shares characteristics of managerial positions with the high dominance of men (CBOS, 2012). The participants ranged between 25 and 55 years old $(M$ age $=36.2$ years, $S D=6.2$ years). The influence of age was controlled and has no significant impact on variables used in the study. All participants were employed full time in a managerial position. They worked within different organizations located in different regions of Poland. The average job tenure was 12.62 years $(S D=6.01)$ and the average number of hours worked per week by the sample was $49.44(S D=9.28)$. The proportion of participants who were married was $68.6 \%(N=94), 26.3 \%(N=36)$ were single and had never married, and $2.9 \%(N=4)$ were divorced.

\section{Procedure}

The study was carried out in 2009 and 2010 and involved a convenience sample of Polish managers who were or had been students on an MBA programme provided by six of the top business schools or universities located in Poland (the position of the schools was assessed on the basis of a national ranking). The selection criteria for participation in the study were as follows: individuals had to work in at least middle-level management, have at least two years of work experience at managerial level, and be working full time in organizations with more than 250 employees. Study packs, which included a statement of informed consent, a demographics sheet, and nine questionnaires (five of which were used in the analysis presented in this paper), were distributed among the participants. The participants were informed that the study was completely anonymous, and they remained unidentified because no personal information was marked on the pack. In addition to the paper and pencil version, the study pack was also available as an electronic version. The paper and pencil version was filled in by 111 people, and 75 people filled in the online form. Owing to the presence of incomplete data for analysis, the results from 137 participants were used in the study (95 completed the paper and pencil version, 42 completed the online form). The influence of the study method (pencil and paper vs. electronic version) was controlled at every stage of analysis. ${ }^{2}$

\section{Measures}

Workaholism Battery. The Spence and Robbins scale has been adapted for use in Poland (Malinowska, Tokarz, \& Gad, 2010) using the translation and backtranslation methodology. It includes three subscales: Feeling Driven to Work/Drive to Work (D), Work Enjoyment (WE), and Work Involvement (WI). Example items are: "I often catch myself thinking about work even when I want to take a break from it" (D); "Most of the time my job is very enjoyable" (WE); "I like to use my time constructively on and off the job" (WI). The participants' task was to score the degree to which each statement conformed to their own experiences, on a five-point Likert scale (1: I definitely agree, to 5: I definitely disagree). For the individual subscales, Cronbach's alpha values were as follows: D = $.71, \mathrm{WE}=.61$, and $\mathrm{WI}=.49$. The subscale Work Involvement was excluded from subsequent analyses because of its low reliability (Cronbach \& Shavelson, 2004). The two remaining subscales enabled assessment of the cognitive and affective dimensions of workaholism, D and WE, respectively.

Work Overload Scale. This scale was developed by Paluchowski and Hornowska (2003, 2007) and includes subscales Lack of control over working and Assumptions about work that assess the cognitive aspects of workaholism. Example items are: "Breaking off from work is not difficult for me"; "My mobile is always on in case there is a phone call from work"; "I experience a lot of stress to get work done on time". The participants' task was to express their opinion about each statement using a five-point scale (1: I definitely disagree or the statement is completely incorrect, to 5: I definitely agree or the statement is completely accurate). The Cronbach's alpha coefficients for these subscales were .82 and .85 .

Time Use Inventory. The Time Use Inventory, which was created by Malinowska et al. (2010), consists of three scales: action, thinking, and emotions. The participants' task was to assess how much time per week (in hours) they devoted to acting and thinking about 10 different life domains (Klinger \& Cox, 2004): sleep, household duties, social life, leisure, spiritual life, work, passion, family, professional development, and an 'other' domain for time unrelated to the categories listed. The instructions controlled for the adequacy of time estimation: the total number of hours devoted to activity could not exceed 168 hours weekly. Participants were also asked to assess their emotions towards each of the domains (e.g., "What

\footnotetext{
${ }^{2}$ The influence of the method on the structure of relationships between variables in the model was insignificant, whereas for cluster analysis it has no impact because this statistical technique is focused on the relationships between variables.
} 
216

Diana Malinowska, Aleksandra Tokarz

emotions do you usually have towards this domain?") using a seven-point scale ( -3 : very negative, to 3 : very positive).

The Time Use Inventory enables the identification of two indicators, or types of imbalance between work and life: Work-life imbalance - thinking and Worklife imbalance - doing. Each indicator includes several diagnostic rules, developed using decision tree algorithms, to classify persons in a given category. Six diagnostic rules concern Work-life imbalance - thinking, e.g. "Thinking about work takes more than $50 \%$ of the time devoted to thinking about all life domains". In the case of Work-life imbalance - doing there are seven rules, e.g. "Devoting 50 or more hours a week to work", and "Time devoted to social life takes less than $4 \%$ of the time devoted to work". The Work-life imbalance - thinking index was used as the cognitive indicator of workaholism. The Work-life imbalance - doing and the number of hours spent weekly on working assess the behavioural indicators of workaholism. The Cronbach's alpha coefficients for the indexes were .91 and .62. The Valence of emotions to work domain, measured by a single item, was treated as one of the affective indicators of workaholism.

Satisfaction with Life Scale. The Satisfaction with Life Scale (SWLS), which was designed by Diener (1984) and adapted for use in Poland by Juczyński (2007), examines the satisfaction with life, achievements, and standards of living of study participants. The SWLS includes five statements that pertain to the cognitive assessment of life as a whole (Pavot \& Diener, 2007). An example item is: "In many aspects my life is almost perfect". The participants' task was to provide their opinions about their lives using a seven-point scale (1: I completely disagree, to 7: I completely agree). The Cronbach's alpha coefficient for the SWLS used in the present study was .85 .

Satisfaction with Individual Domains Scale. This instrument, which was designed by Czapiński (2000), enables researchers to assess participants' satisfaction with different aspects of life. In the initial version used in the present study, the scale included 16 aspects that encompassed almost all the interests and activities of an average person (Czapiński, 2000). The participants' task was to assess their level of satisfaction with each of the 16 aspects using a six-point scale (1: very dissatisfied, to 6: very satisfied). Exploratory factor analysis (EFA) was conducted on the data gathered in the present study to sort these aspects into interpretable and more general categories. On this basis, two domains of satisfaction, which consisted of 10 and four aspects each (two aspects were dropped from the scale because of low eigenvalues), were selected from the scale for further analysis in the present study. These domains corresponded to: Satisfaction with self-realization (e.g., education, available goods and services, future prospects, life achievements, children, sexual life) and Satisfaction with life situation (e.g., marriage, financial situation, state of health). Example items are: "To what extent are you satisfied with your life achievements?" and "To what extent are you satisfied with your state of health?". The Cronbach's alpha coefficient was satisfactory for Satisfaction with selfrealization (.84) and minimally acceptable (DeVellis, 2003) for Satisfaction with life situation (.65).

\section{Results}

\section{Structure of Workaholism}

The first step in the data analysis was to undertake Confirmatory Factor Analysis (CFA) using AMOS 17.0 in order to reject or validate the models tested on the basis of the fit of their indicators (Kaplan, 2000). The adequacy of the size of the sample in the structural equation model was based on two goodness-of-fit statistics: the value of the $90 \%$ confidence interval of the root mean square error of approximation (RMSEA) and Hoelter's critical N value, which was confirmed to be appropriate in the present study.

Two models were tested. The first model (M3) assumes that workaholism has a three-dimensional structure composed of behavioural, cognitive, and affective dimensions, in accordance with the theoretical proposition of $\mathrm{Ng}$ and his colleagues (2007). The second model (M1) was a competitive model. It assumes that workaholism has a one-dimensional structure and that all indicators of workaholism belong to the same latent construct.

The descriptive statistics and the measurements of reliability of the scales that were used during the CFA can be found in Table 2.

Table 2. Means $(M)$, Standard Deviations $(S D)$, and Internal Consistencies (Cronbach's $\alpha$ ) of the Study Variables Used in the Investigation of the Structure of Workaholism

\begin{tabular}{lccc}
\hline Variable & $M$ & $S D$ & $\alpha$ \\
\hline Drive to work & 23.1 & 6.0 & .71 \\
Work enjoyment & 11.8 & 3.0 & .61 \\
Lack of control over working & 49.2 & 10.2 & .82 \\
Assumptions about work & 45.9 & 10.6 & .85 \\
Time spent working* & 49.1 & 10.1 & - \\
Valence of emotions related to & 1.3 & 1.2 & - \\
work & .8 & 1.7 & .91 \\
Work-life imbalance - thinking & 2 & 1.5 & .62 \\
Work-life imbalance - doing & 2 & & \\
\hline
\end{tabular}

Note. * Number of hours per week.

The results of the CFA, which are presented in Table 3 , validate the three-dimensional model of workaholism (M$3)$. The value of the Comparative Fit Index $(\mathrm{CFI}=1.0)$ was higher than the acceptable threshold of .90 (Byrne, 2001). In addition, RMSEA, which was lower than .05, indicated that the model showed a good level of fit. The chi-square test, which compares the theoretically assumed structure of the data with the observed values, produced a statistically insignificant value $\left(x^{2}=4.30 ; p=.99\right)$. The competitive model (M-1) showed a poorer fit to the data $(\mathrm{RMSEA}=.06$, $\left.\mathrm{CFI}=.90, x^{2}=30.67 ; p=.06\right)$. (Table 3 - see page 217$)$ 
The Structure of Workaholism and Types of Workaholic

Table 3. Results of Confirmatory Factor Analysis: Significance Test and Fit Indices of Three- and OneDimensional Models of Workaholism

\begin{tabular}{lcccccc}
\hline Model & & $x^{2}$ & $d f$ & $p$ & RMSEA & CFI \\
\hline 1-Dimensional Model & M-1 & 30.67 & 20 & .06 & .06 & .90 \\
3-Dimensional Model & M-3 & 4.30 & 17 & .99 & $<.001$ & 1 \\
\hline
\end{tabular}

Figure 2. Results of Confirmatory Factor Analysis: Three-Dimensional Structure of Workaholism.

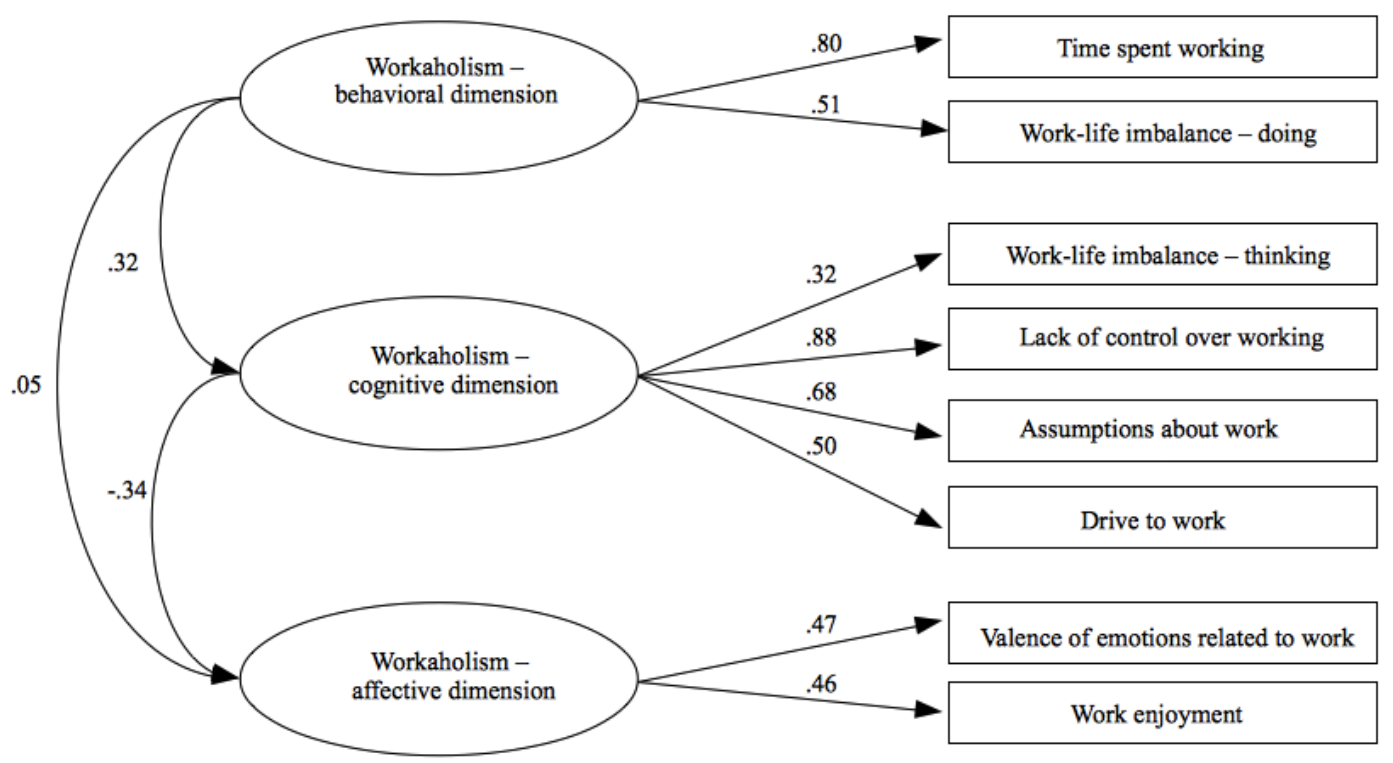

Table 4. Means (M), Standard Deviations (SD), Internal Consistencies (Cronbach's $\alpha$ ), and Intercorrelations of the Variables Used in the Cluster Analysis

\begin{tabular}{|c|c|c|c|c|c|c|c|c|}
\hline Variable & $M$ & $S D$ & $\alpha$ & 1 & 2 & 3 & 4 & 5 \\
\hline 1. Workaholism - behavioural dimension & .00 & 1.48 & - & & & & & \\
\hline 2. Workaholism - cognitive dimension & .02 & 8.85 & - & $.24 * *$ & & & & \\
\hline 3. Workaholism - affective dimension & .04 & 0.99 & - & -.01 & $-.18^{*}$ & & & \\
\hline 4. Satisfaction with self-realization & 46.32 & 6.40 & .84 & -.06 & -.10 & .14 & & \\
\hline 5. Satisfaction with life situation & 18.58 & 2.93 & .65 & -.07 & -.14 & .11 & $.55^{* *}$ & \\
\hline 6. General satisfaction with life & 23.25 & 4.94 & .85 & -.05 & -.16 & $.25^{* *}$ & $.42 * *$ & $.40 * *$ \\
\hline
\end{tabular}

Note. $* p<.05, * * p<.001$

As can be seen from Figure 2, the latent factors for the cognitive dimension and behavioural dimension were positively correlated $(r=.32)$, whereas the cognitive dimension was negatively correlated with the affective dimension $(r=-.34)$. In contrast, no significant correlation existed between the behavioural and affective dimensions of workaholism.

\section{Types of Workaholic}

To determine the different types of workaholic, cluster analysis available in SPSS was conducted on the basis of the evaluation of the latent variables that were identified in the CFA (the estimation of workaholism dimensions was based on reverse regression equations, in which the coefficient of determination was used as a weight for the relevant observed variables) and three aspects of quality of life. Table 4 presents the means, standard deviations, Cronbach's alpha coefficients, and intercorrelations of the variables used in the cluster analysis.

The algorithm of hierarchical agglomerative cluster analysis was used for the analysis and the Pearson correlation coefficient, $r$, was used to measure the distances between variables.

The results of the cluster analysis showed clearly that there were three clusters of employees. Table 5 shows the characteristics of the individual clusters (means for the dimensions of workaholism, number of hours spent working per week, number of employees per cluster/type, and percentage of the sample). Eleven individuals did not fit into any of the clusters and were dropped from the analysis. 
Table 5. Results of Cluster Analysis: Mean Scores for Dimensions of Workaholism, Evaluation of Satisfaction, and Characteristics of Cluster/Type

\begin{tabular}{|c|c|c|c|}
\hline \multirow{3}{*}{ Variable } & Cluster 1 & Cluster 2 & Cluster 3 \\
\hline & $\begin{array}{l}\text { Partially satisfied } \\
\text { workaholic }\end{array}$ & $\begin{array}{c}\text { Satisfied } \\
\text { non-workaholic }\end{array}$ & $\begin{array}{l}\text { Dissatisfied } \\
\text { workaholic }\end{array}$ \\
\hline & \multicolumn{3}{|c|}{ M } \\
\hline Workaholism - behavioural dimension & .49 & -.45 & -.06 \\
\hline Workaholism - cognitive dimension & -.49 & -.58 & .59 \\
\hline Workaholism - affective dimension & .37 & -.00 & -.21 \\
\hline Satisfaction with self-realization & .20 & .54 & -.48 \\
\hline Satisfaction with life situation & -.32 & .85 & -.30 \\
\hline General satisfaction with life & .41 & .44 & -.58 \\
\hline Number of hours spent weekly on working* & 52.3 & 46.9 & 49.2 \\
\hline Number of employees per cluster/type & 30 & 37 & 58 \\
\hline Percentage of the sample & 21.9 & 27 & 42.3 \\
\hline
\end{tabular}

Note. *The number of hours spent weekly on working was not one of the clustering criteria.

Cluster 1 included individuals who had above average scores in the behavioural and affective dimensions of workaholism and below average scores in the cognitive dimension of workaholism. Persons who belonged to this cluster scored above the average for satisfaction with selfrealization and general satisfaction with life. However, their scores for satisfaction with their life situation were below average. They could be described as partially satisfied workaholics. The members of this cluster worked 52 hours per week on average. The cluster consisted of 30 persons, i.e. $21.9 \%$ of the total number of participants in the study. Cluster 2 included persons who scored below average in the behavioural, cognitive, and affective dimensions of workaholism, but above average in every aspect of quality of life (satisfaction with self-realization, satisfaction with life situation, and general satisfaction with life). They may be described as satisfied non-workaholics. The members of this cluster worked 47 hours per week on average. The cluster included 37 individuals, equivalent to $27 \%$ of the participants in the study.

Cluster 3 included individuals who scored above average in the cognitive dimension of workaholism and below average in the behavioural and affective dimensions of workaholism. They could be described as dissatisfied workaholics. These persons scored below the average in all three aspects of quality of life and worked approximately 49 hours per week on average. The cluster consisted of 58 persons, which equated to $42.3 \%$ of the participants.

\section{Discussion}

\section{Structure of Workaholism}

The results of the study verify the structure of workaholism that was proposed by $\mathrm{Ng}$ et al. (2007). The data obtained confirm hypothesis 1 , which describes the multidimensional structure of workaholism. Therefore, rather than a unitary concept, workaholism should be treated as a syndrome, i.e. a collection of factors (Aziz \& Zickar, 2006), with three key dimensions: behavioural, cognitive, and affective.
Two indicators were identified in the behavioural dimension: Time spent working and Work-life imbalancedoing. It is important to note that, in previous studies, the number of hours worked per week was considered either to be the only behavioural indicator or was considered in conjunction with another indicator, namely, control of the level of financial needs (Harpaz \& Snir, 2003; Snir \& Zohar, 2008). Undoubtedly, it is necessary to be able to identify workaholism on the basis of behavioural indicators that represent other qualities related to time, such as work-life imbalance (Bonebright et al., 2000; Cherrington, 1980; Ng et al., 2007). The salience of one life domain/activity is an important indication of functional dependence (Griffiths, 2005a, 2005b, 2005c). The indicator Work-life imbalancedoing refers to the aforementioned imbalance between work and other life domains. The diagnosis of an imbalance is based on a number of hours of work per week that exceeds 50 , but also includes the number of hours devoted to professional development (training, postgraduate studies) and a small amount of time devoted to other life domains (especially leisure and social life).

The findings described herein indicated that the cognitive dimension of workaholism is related to obsession about work and that it describes the way in which a workaholic individual thinks about work when not working, their feeling of loss of control over the performance of professional duties, their irrational views of work that make them work long hours, and their strong internal drive to work hard.

Workaholism is usually operationalized by means of indicators that reflect the cognitive dimension. These are applied solely to diagnose workaholism that is treated as a symptom of dysfunction related to obsessive-compulsive disorder or features of addiction (Haymon, 1992; Mudrack, 2004; Robinson, 1989; Wojdyło, 2004, 2005). The cognitive dimension of workaholism that was identified in the present study included aspects related to thinking about work, and imbalance in the time devoted to thinking about work and other life domains. Many researchers, such as Robinson (1996), emphasize that workaholics find it difficult to 
disconnect from work and are unable to stop thinking about it even when they are not working.

Another important indicator that belongs to the cognitive dimension of workaholism concerns the person's view of work. Paluchowski and Hornowska (2003, 2007) point out the existence of 'cognitive schemes' that are related to treating work as an issue of personal ethics or even religion and describe these as being among the subjective causes of workaholism. Similarly, Retowski (2003) indicates that the 'Protestant work ethic' and views related to it might be a crucial factor in the development of workaholism.

A further indicator that belongs to the cognitive dimension of workaholism is compulsion to work. This indicator refers to a strong internal need to work without any external reasons, such as to meet one's own financial needs or the requirements of supervisors, and is related to an internal sense of duty (Spence \& Robbins, 1992). As indicated by Schaufeli, Taris, and van Rhenen (2008), for workaholics, this drive is compulsive in nature and differentiates workaholics from 'engaged employees', who do not demonstrate compulsion.

Lack of control was also identified in the present study among the cognitive indicators of workaholism. This indicator is mentioned by other researchers (e.g., Cherrington, 1980; Oates, 1971; Smith \& Seymour, 2004), who emphasize that obsession about work leads to an almost irrational involvement in work, which may not be limited or controlled.

Another dimension of workaholism that was identified in the present study was the affective dimension, which involves the indicators Valence of emotions related to work and Work enjoyment. These two indicators make it possible to identify workaholism on the basis of positive emotions related to work and satisfaction with work. Individuals who obtain high scores on these indicators treat work as pleasure: it is interesting and stimulating for them, and they see it more as fun than work. Researchers indicate that workaholics may experience positive emotions such as happiness and pleasure from working (e.g., Bonebright et al., 2000; Keichel, 1989; Machlowitz, 1980; Spence \& Robbins, 1992). However, there are reports that workaholics also feel negative emotions, e.g. fear and feelings of guilt or even depression when they are not working (Morris \& Charney, 1983; Scott et al., 1997). The lack of available tools to measure the affective aspect of workaholism means that currently it is necessary to adjust the existing scales that measure emotion (e.g., the Positive and Negative Affect Schedule) to the context of studies on this phenomenon.

It should be added that the pattern of relationships among the three dimensions of workaholism was slightly different from that expected by the authors of the multidimensional typology. $\mathrm{Ng}$ and his colleagues (2007) assumed that these three dimensions would be positively correlated. The negative correlation between the cognitive and affective dimensions implies that those who are internally driven and obsessed with work do not find joy in their work, which is consistent with previous studies (e.g., Schuafeli et al., 2008). The lack of a significant correlation between the behavioural and affective dimensions could be interpreted as showing that these two aspects are orthogonal. However, this result is not in line with the empirical evidence (e.g., Burke \& Koksal, 2002; McMillan et al., 2004). An alternative explanation is that the lack of correlation might be caused by the insufficient manifestation of the affective dimension in the assumed structure of workaholism. This dimension was measured with only one scale and a single question. It might be necessary to take more specific indicators of the affective dimension into account, e.g. the positive and negative emotions that are felt by an individual when they are working or not working.

\section{Types of Workaholic}

The second main aim of the study was to identify various types of workaholic. Hypothesis 2, which proposed that there are functional and dysfunctional types of workaholic based on workaholism dimensions who differ with regard to their subjective assessment of quality of life, was also confirmed.

To interpret in detail the qualities of employees who had high scores for various dimensions of workaholism, one may refer to the employee typologies proposed by Naughton (1987) and Schaufeli et al. (2006), which both include 'the workaholic'.

The workaholic involved in work described by Naughton (1987) is characterized by the following qualities: possession of a high level of involvement in work and low level of obsession-compulsion, deriving a lot of satisfaction from work, and having little interest in activities unrelated to work. All these qualities were present in the individuals who were classified as belonging to cluster 1 . It must be noted that the existence of the internal drive to work and obsession about work is crucial in the diagnosis of addiction. In Griffiths' (2005a, 2005b, 2005c) model of addiction, one of the fundamental characteristics of addiction is the salience of one activity over others; this addictive activity dominates the person's behaviour, thoughts, and feelings.

The analyses discussed here showed the dominance of one activity in the behavioural and affective dimensions of employees who belonged to cluster 1 , partially satisfied workaholics. They shared some qualities with engaged employees (Bakker, Schaufeli, Leiter, \& Taris, 2008; Schaufeli et al., 2006): complete devotion and preoccupation with work, neglect of other commitments, lack of compulsion to work, and lack of guilt if not working. However, partially satisfied workaholics do not manifest one of the qualities listed by Schaufeli et al. (2006), namely, satisfaction with life outside work. They were not satisfied fully with their family, material situation, and health. Thus, they may not be regarded as engaged employees, who have a high level of satisfaction with life domains other than work. It could be suggested that cluster 1 reveals an initial stage in the development of an addiction to excessive work. This is similar to other addictions, which include substance abuse and the necessity to perform a given activity (Juczyński, 2008). This result is consistent with the data obtained in other studies (e.g., Bonebright et al., 2000; 
Spence \& Robbins, 1992; Bakker, Demerouti, \& Burke, 2009), and it suggests that workaholics may suffer negative consequences in certain life domains.

Partially satisfied workaholics maintain a positive assessment of life and in general are satisfied with life and, more specifically, with the life domains that are related to their own causative power (achievements, available services, workplace, children). This result is especially important to bear in mind when seeking a functional type of workaholic. As Miquelon and Vallerand (2006) demonstrated, selfrealization contributes the most to the relationship between satisfaction and objective indicators of health. The authors claim that self-realization is related to the mental strength or resources that a person may tap into to cope with challenges and difficult situations (Antonovsky, 1979, 1995).

With respect to the dissatisfied workaholics, who belonged to cluster 3, they showed all the qualities that are attributed to the workaholic (Schaufeli et al., 2006), the obsessive-compulsive workaholic (Naughton, 1987), and the obsessive-addicted workaholic (Scott et al., 1997). These characteristics include: a high level of compulsion and involvement in work; an internal drive to work, which may not be limited or controlled; and a negative assessment of one's state of health. It could be argued that dissatisfied workaholics are in an advanced stage of work dependence (Juczyński, 2008). They score high on the cognitive aspects related to work obsession and could be described as bonded obsessively to their work.

The assessment of their quality of life by dissatisfied workaholics was definitely lower than that of other types of employee identified. They were less satisfied with all three aspects of quality of life: general satisfaction with life, satisfaction with self-realization, and satisfaction with life situation. Similar results have been obtained in other studies (e.g. Robinson et al., 2006), in which workaholics were identified primarily on the basis of cognitive indicators. Moreover, Diener, Lucas, and Scollon (2006) confirmed that persons with diagnosed pathologies score low on satisfaction with life, as measured by the SWLS. Therefore, it appears to be justified to assume that dissatisfied workaholics should be included in the dysfunctional group.

\section{Implications of the Study}

Although the research on workaholism has increased over the past decade, few studies have examined the structure of workaholism and types it may adapt. Thus, the main purpose of this study was to investigate the multidimensional structure of workaholism and identified workaholics types based on the empirically verified structure and with regard to the quality of life. Our results extend the literature about workaholism in a number of important ways.

In terms of theoretical implications, the present investigation has provided support for a multidimensional structure of workaholism, which thus should be treated as a syndrome. The results indicate that the combination of scores for the three dimensions of workaholism (behavioural, cognitive, and affective), in connection with the assessment of quality of life, can be used to identify various types of workaholic.

The types of workaholic identified here differ with regard to the characteristics seen in other addictions and/or obsessive-compulsive disorders, as well as in the assessment of their quality of life. With respect to the discussion of normality and pathology in addictive behaviour (Habrat, 2000), it is interesting that only partially satisfied workaholics defined herein manifested a low score for the cognitive indicators of workaholism, and, as already mentioned, this type did not share common features with obsessive-compulsive disorders or addictions (Meyer, 2003; Paluchowski \& Hornowska, 2007). On the theoretical level, this result might indicate that workaholism (probably in its early stages) might also be part of a broadly understood normality (Habrat, 2000). Moreover, this study is a welcome attempt to restore some balance to the research on workaholism and is likely to stimulate a substantial number of new studies.

The findings presented herein also have practical implications. It is essential that managers of human resources pay attention not only to the work habits of employees but also to the symptoms of workaholism that are related to cognition and the emotions. The conceptualization of $\mathrm{Ng}$ et al. (2007) provides direct definitions of the indicators that might be used in the process of employee appraisals. It is beneficial for organizations to diagnose the positive and negative types of workaholic in their workforce and to compare the performance and professional efficacy of these two types. Moreover, human resource practitioners need to disseminate and update knowledge about workaholism and the types of workaholic among employees on a regular basis. In this way, they will make people more aware of workaholism and might be able to shape an organizational culture that places emphasis on the health and well-being of employees.

\section{Limitations of the Study and Potential Directions for Future Research}

The present study only used data derived from selfadministered questionnaires. In the context of research on addictions it is crucial to adopt a multi-method approach, supplementing self-descriptive methods with, for example, interviews with workaholics, their family members, and work colleagues.

There is also a need to develop further survey instruments that measure indicators of workaholism. It should be noted that problems with the inadequate reliability of the Work involvement scale have appeared in other studies conducted outside the USA (e.g., Ersoy-Kart, 2005). Therefore, it might be useful to create new scales that capture adequately the distinct meaning of indicators of workaholism in different cultures.

Another limitation is related to the cross-sectional design of the study. A longitudinal study design is important for two reasons. First, such an approach enables the development of the phenomenon to be investigated over 
time. It needs to be verified empirically whether indicators of the syndrome that are related to the functional type of workaholic occur at the initial stage of workaholism and whether prolonged behaviour that is related to devotion mainly to work leads to obsession. Second, it should be possible to identify the short- and long-term consequences of workaholism. It may be supposed that, as for other addictions (e.g., Juczyński, 2008), the consequences will differ depending on the stage of workaholism (early or more advanced).

Furthermore, the structure of workaholism and types of workaholic need to be verified in other studies with samples that represent not only managers but also different occupations. Further research could benefit greatly from including other variables that are related to objective indicators of health and work effectiveness, to allow better differentiation between functional and dysfunctional types of workaholic.

\section{References}

Antonovsky, A. (1979). Health, stress and coping: New perspectives on mental and physical well-being. San Fransisco: Jossey Bass.

Antonovsky, A. (1995). Rozwikłanie tajemnicy zdrowia: o tym jak radzic sobie ze stresem i nie zachorować [Unraveling the mystery of health how people manage stress and stay well]. Warszawa: Fundacja IPN.

Aziz, S. \& Zickar, N. J. (2006). A cluster analysis investigation of workaholism as a syndrome. Journal of Occupational Health Psychology, 11, 52-62.

Bakker, A. B., Schaufeli, W. B., Leiter, M. P., \& Taris, T. W. (2008). Work engagement: An emerging concept in occupational health psychology. Work \& Stress, 22, 187-200

Bakker, A. B., Demerouti, E., \& Burke, R. (2009). Workaholism and relationship quality: A spillover-crossover perspective. Journal of Occupational Health Psychology, 14, 23-33

Bonebright, C. A., Clay D. L., \& Ankenmann, R. D. (2000). The relationships of workaholism with work-life conflict, life satisfaction, and purpose in life. Journal of Counseling Psychology, 47, 69-477.

Buelens, M. \& Poelmans, S. A. Y. (2004). Enriching the Spence and Robbins's typology of workaholism. Demographic, motivationa and organizational correlates. Journal of Organizational Change Management, 17, 440-458.

Burke, R. J. (2000a). Workaholism in organizations: the role of personal beliefs and fears. Anxiety, Stress, and Coping, 13, 53-64.

Burke, R. J. (2000b). Workaholism in organizations: Concepts, results and future research directions. International Journal of Management Reviews, 2, 1-16.

Burke, R. J. (2001). Workaholism in organizations: Psychological and physical well-being consequences. Stress Medicine, 16, 11-16.

Burke, R. J. \& Koksal, H. (2002). Workaholism among a sample of Turkish managers and professionals: an exploratory study. Psychological Reports, 91, 60-68.

Burke, R. J. \& Fiksenbaum, L. (2008). Work Motivations, Work Outcomes, and Health: Passion Versus Addiction. Journal of Business Ethics, $84,257-263$

Byrne, B. M. (2001). Structural equation modeling with AMOS: Basic concepts, applications, and programming. Mahwah, NJ: Erlbaum.

Cantarow, E. (1979). Women workaholism. Mother Jones, 6, 56

CBOS (2012). Mobliność na codzień. Komunikat z badań nr BS/104/2012. Warszawa.

Cierpiałkowska, L. \& Sęk, H. (2006). Zdrowie i zaburzenia z perspektywy rozwojowej i procesualnej. Próba integracji podejścia salutogenetycznego i patogenetycznego [Health and disorders from developmental and procesual perspectives. An attempt to integrate salutogenetic and pathogenetic approaches]. In T. Pasikowski \& H. Sęk (Eds.), Psychologia zdrowia: teoria, metodologia i empiria (pp. 21-41). Poznań: Bogucki Wydawnictwo Naukowe.

Cherrington, D. J. (1980). The work ethic. New York: American Management Association.
Cronbach, L. J. \& Shavelson R. J. (2004). My Current Thoughts on Coefficient Alpha and Successor Procedures. Educational and Psychological Measurement, 64, 391-418.

Czapiński, J. (2000). Stan zdrowia psychicznego - wskaźniki niekliniczne [State of psychical health - non-clinical indicators]. In J. Cz. Czabała (Ed.), Zdrowie psychiczne. Zagrożenia i promocja (pp. 231-296). Warszawa: Instytut Psychiatrii i Neurologii.

DeVellis, R. F. (2003). Scale Development: Theory and Applications, Second Edition. Thousand Oaks, CA: Sage Publications.

Diener, E. (1984). Subjective well-being. Psychological Bulletin, 95, $542-575$.

Diener, E. (2006). Guidelines for National Indicators of Subjective WellBeing and Ill-Being. Applied Research in Quality of Life, 1, 151-157.

Diener, E., Lucas, R. E., \& Scollon, C. N. (2006). Beyond the hedonic treadmill: Revising the adaptation theory of well-being. American Psychologist, 61, 305-314.

Ersoy-Kart, M. (2005). Reliability and validity of the Workaholism Battery (WorkBAT): Turkish form. Social Behavior and Personality: An international Journal, 33, 609-618.

Flett, G.L., \& Hewitt, P. L. (2006). Positive versus negative aspects of perfectionism in psychopathology: A comment on Slade and Owen's dual process model. Behavior Modification, 30, 11-24

Griffiths, M. D. (2005a). A "components" model of addiction within a biopsychosocial framework. Journal of Substance Use, 10, 191-197.

Griffiths, M. D. (2005b). The biopsychosocial approach to addiction. Psyke \& Logos (Journal of the Danish Psychological Society), 26, 9-26.

Griffiths, M. D. (2005c). Workaholism is still a useful construct. Addiction Research and Theory, 13, 97-100.

Habrat, B. (2000). Uzależnieniowa wizja świata [Addictive world perspective]. Postępy Psychiatrii i Neurologii, 9, 491-493.

Harpaz, I. \& Snir, R. (2003). Workaholism: Its definitions and nature. Human Relations, 56, 291-391.

Haymon, S. (1992). The relationship of work addiction with depression, anxiety, and anger in collage males. Unpublished doctoral desideration, Florida State University, Tallahassee.

Hewlett, S. A. \& Luce, C. B. (2006). Extreme Jobs: The dangerous allure of the 70-hour work week. Harvard Business Review, December, 49-59.

Heszen, I. \& Sęk I. (2007). Psychologia zdrowia [Health psychology]. Warszawa: PWN

Juczyński, Z. (2007). Narzędzia pomiaru $w$ psychologii $w$ promocji psychologii zdrowia [Measurement instruments in psychology in promotion and health psychology]. Warszawa: Pracownia Testów Psychologicznych.

Juczyński, Z. (2008). Dylematy i kontrowersje wokół uzależnień [Dilemmas and controversies about addictions]. In J. M. Brzeziński \& L. Cierpiałkowska (Eds.), Zdrowie i choroba. Problemy teorii, diagnozy i praktyki (pp. 190-212). Gdańsk: GWP.

Kaplan, D. (2000). Structural equation modeling: foundations and extensions. Thousand Oaks, CA: Sage.

Keichel, W. (1989). The workaholic generation. Fortune, 119, 50-62.

Killinger, B. (1991). Workaholics: The respectable addicts. New York: Simon \& Schuster.

Lafrenière, M.-A. K., Jowett, S., Vallerand, R. J., Donahue, E. G., \& Lorimer, R. (2008). Passion in sport: On the quality of the coachathlete relationship. Journal of Sport and Exercise Psychology.

Levine, S. (1995). The meanings of health, illness and quality of life. In I Guggenmoos-Holtzmann, K. Bloomfield \& U. Flick (Eds.), Quality of life and health: concepts, methods and applications (pp. 7-13). Berlin: Blackwell Wissenschafts-Verlag.

Klinger, E. \& Cox, W. M. (2004). The Motivational Structure Questionnaire and Personal Concerns Inventory: Psychometric Properties. In M. Cox \& E. Klinger (Eds.) Handbook of motivational counseling: Concepts, approaches, and assessment. (pp. 177-197). Chichester: Jon Wiley \& Sons.

Latham, G. P. (2007). Work motivation. History, theory, research, and practice. Thousands Oaks, CA: Sage.

Machlowitz, M. (1980). Workaholics. Addison Wesley, Reading, MA.

Madsen, K.B. (1974). Modern Theories of Motivation. Copenhagen. [Wyd. pol.Współczesne teorie motywacji. Warszawa: PWN.]

Malinowska, D. (2014). Pracoholizm jako zjawisko wielowymiarowe. [Workaholism as a multidimensional phenomenon]. Kraków: Wydawnictwo Uniwersytetu Jagiellońskiego.

Malinowska, D., Jochymek, S., \& Tokarz, A. (2010, March). The assessment of workaholism as a work-life imbalance: 'Time Usage 
Inventory' development and preliminary empirical testing. Poster session presented at the 9th Conference of the European Academy of Occupational Health Psychology, Pontifical Urbaniana University, Rome.

Malinowska, D., Trzebińska, M., Tokarz, A., \& Kirkcaldy, B. D. (2013) Workaholism and Psychosocial Functioning: Individual, Family and Workplace Perspectives. In C. Cooper \& A. S. Antoniou (Eds.). The Psychology of the Recession on the Workplace (pp. 257-270). Edward Elgar.

Malinowska, D., Tokarz, A., \& Gad, N. (2010). Wstępne badania nad adaptacją skali Workaholism Battery (Work-BAT) Spence i Robbins [The scale adaptation primarily study of Spence and Robbins Workaholism Battery (Work-BAT)]. Studia Psychologiczne, 48, 35-42.

Malinowska, D. \& Tokarz, A. (2013). Understanding functional and dysfunctional types of workaholic: An investigation based on motivational characteristics. Acta Psychoneurologica, 11, 19-36.

Malinowska, D. \& Tokarz, A. (2014). Psychologiczna charakterystyka osób pracujacych nadmiernie: różne postaci zaangażowania w prace [Psychological characteristic of overworked employees: differen types of work engagament]. Studia Humanistyczne AGH, 13, 79-99.

McClelland, D.C. (1986). Human Motivation. Glenview: Scott, Foresman and Co.

McMillan, L. H. W., O’Driscoll, M. P., \& Brady, E. C. (2004). The impact of workaholism on personal relationships. British Journal of Guidance and Counselling, 32, 171-186.

Meyer, R. (2003). Psychopatologia. Jeden przypadek - wiele teori [Psychopathology. One case - many theories]. Gdańsk: GWP.

Miquelon, P. \& Vallerand, R. J. (2006). Goal motives, well-being, and physical health: happiness and self-realization as psychologica resources under challenge. Motivation and Emotions, 30, 259-272.

Morris, S. \& Charney, N. (1983). Workaholism: Thank god it's Monday. Psychology Today, 17, 88.

Mudrack, P. (2004). Job involvement, obsessive-compulsive personality traits, and workaholic behavioral tendencies. Journal of Organizational Change Management, 17, 490-507.

Nakamura, J. \& Csikszentmihalyi, M. (2003). The motivational sources of creativity as viewed from the paradigm of positive psychology. In L. G. Aspinwall \& U. M. Staudinger (Eds.), A Psychology of Human Strengths (pp. 257-270). Washington, DC: American Psychological Association.

Naughton, T. J. (1987). A conceptual view of workaholism and implications for career counseling and research. The Career Development Quarterly, 180-187.

Ng, W. H., Sorensen, K. L., \& Feldman, D. C. (2007). Dimensions, antecedents, and consequences of workaholism: A conceptual integration and extension. Journal of Organizational Behavior, 28 111-136.

Oates, W. (1971). Confessions of a workaholic: The facts about work addiction. New York: World Publishing.

Paluchowski, W. J. \& Hornowska, E. (2003). Pracoholizm a system wartości i uwarunkowania temperamentalne [Workaholism and values systems and temperamental determinants]. In S. A. Witkowski (Ed.), Psychologiczne wyznaczniki sukcesu w zarzadzaniu. Tom IV (pp. 259319). Wrocław: Wydawnictwo Uniwersytetu Wrocławskiego.

Paluchowski, W. J. \& Hornowska, E. (2007). Praca - skrywana obsesja [Workaholism - the hidden obsession]. Poznań: Bogucki.

Pavot, W. \& Diener, E. (2007). The Satisfaction With Life Scale and the emerging construct of life satisfaction. The Journal of Positive Psychology, 3, 137-152.

Philippe, F. L., Vallerand, R. J., Andrianarisoa J., \& Brunel, P. (2009). Passion in referees: Examining their affective and cognitive experiences in sport situations. Journal of Sport \& Exercise Psychology, 31, 77-96.

Porter, G. (1996). Organizational impact of workaholism: Suggestion for researching the negative outcomes of excessive work. Journal of Occupational Health Psychology, 1, 1-15.

Retowski, S. (2003). Pracoholizm - próba teoretycznego zdefiniowania zjawiska [Workaholism - the theoretical attempt to define the phenomenon]. In B. Wojaszke \& M. Plopa (Eds.), Osobowość a procesy psychiczne i zachowanie (pp. 313-343). Kraków: Impuls.

Robinson B. E. (1989). Work addiction. Deerfield Beach, FL: Heath Communication
Robinson B. E. (1996). The psychosocial and familial dimension of work addiction: Preliminary perspective hypotheses. Journal of Counseling and Development, 74, 447-452.

Robinson, B. E. (1998). Chained to the desk: A guidebook for workaholics, their partners and children, and the clinicians who treat them. New York: New York University Press.

Robinson, B. E. (2000). Workaholism: Bringing the gap between workplace, sociocultural, and family research. Journal of Employment Counseling, 37, 31-47.

Robinson, B. E., Flowers, C. \& Ng, K-M. (2006). The relationship between workaholism and marital disaffection: Husbands' perspective. The Family Journal: Counseling and Therapy for Couples and Families, 14, 213-220.

Rohrlich, J. B. (1981). The dynamics of work addiction. The Israel Journal of Psychiatry and Related Sciences, 18, 147-156.

Scott, K. S., Moore, K. S. \& Miceli, M. P. (1997). An exploration of the meaning and consequences of workaholism. Human Relations, 50, 287-314.

Schaufeli, W. B., Taris, T. W., \& Bakker, A. B. (2006). Dr Jekyll or Mr Hyde? On the difference between work engagement and workaholism. In R. Burke (Ed.), Workaholism and long hours working (pp.193217). Cheltenham: Edward Elgar.

Schaufeli, W. B., Taris, T. W., \& van Rhenen, W. (2008). Workaholism, burnout, and work engagement: Three of a kind or three different kinds of employee well-being? Applied Psychology: An International Review, 57, 173-203.

Seligman, M. E. P. \& Csikszentmihalyi, M. (2000). Positive Psychology: An introduction. American Psychologist, 55, 5-14.

Shimazu, A., \& Schaufeli, W.B. (2009). Is workaholism good or bad for employee well- being? The distinctiveness of workaholism and work engagement among Japanese employees. Industrial Health, 47, 495502.

Smith, D. E. \& Seymour, R. B. (2004). The nature of addiction. In R. H. Coombs (Ed.), Handbook of addictive disorders: A practical guide to diagnosis and treatment (pp. 3-30). New Jersey: John Wiley \& Sons, Inc.

Snir, R. \& Zohar, D. (2008). Workaholism as discretionary time investment at work: An experience-sampling study. Applied Psychology: An International Review, 57, 109-127.

Spence, J. T. \& Robbins, A. S. (1992). Workaholism: Definition, measurement, and preliminary results. Journal of Personality Assessment, 58, 160-178.

Szczucka, K. (2010). Polski Kwestionariusz Perfekcjonizmu Adaptacyjnego i Dezadaptacyjnego [Polish Questionnaire of Adaptive and Nonadaptative Perfectionism]. Psychologia Spoleczna, 1, 71-95.

van Beek, I., Taris, T., \& Schaufeli, W. B. (2011). Workaholic and Work Engaged Employees: Dead Ringers or Worlds Apart? Journal of Occupational Health Psychology, 16, 468-482.

Veenhoven, R. (1988). The utility of happiness. Social Indicators Research, 20, 333-354.

Veenhoven, R. (1991). Questions on Happiness: Classical topics, modern answers, blind spots. In F. Strack, M. Argyle, N. Schwarz, (Eds.), Subjective Well Being: An interdisciplinary approach (pp. 7-26). Britan: Pergamon Press.

Vodanovich, S. J., Piotrowski, C., \& Wallace, J. C. (2007). The relationship between workaholism and health: A report of negative findings. Organization Development Journal, 25, 70-75.

Wilson, I. B. \& Cleary, P. D. (1995). Linking clinical variables with healthrelated quality of life. A conceptual model of patient outcomes. Journal of American Medical Association, 273, 59-65.

Wojdyło, K. (2004). Pracoholizm - rozważania nad osobowościowym wyznacznikami obsesji pracy [Workaholism - considerations on personality determinants of the work obsession], Nowiny Psychologiczne, 2, 55-75.

Wojdyło, K. (2005). Kwestionariusz Pracoholizmu (WART) - adaptacja narzędzia i wstępna analiza własności psychometrycznych [Workaholism Questionnaire (WART) - the instrument's adaptation and primary analysis of its psychometrical properties], Nowiny Psychologiczne, 4, 71-84. 